\title{
Relationship between AgNOR proteins, Ki-67 antigen, p53 immunophenotype and differentiation markers in archival breast carcinomas
}

\author{
Àgnes Bànkfalvi, Klaus Schmitz, Tobias Mock, Mechthild Kemper, Christiane Cubick \\ and Werner Böcker* \\ Domagk Institute of Pathology, University of Münster, Domagkstrasse 17, D-48149 Münster, Germany
}

Received 15 October 1998

Revised 11 December 1998

Accepted 26 January 1999

\begin{abstract}
The present study investigated (i) the relationship between standardised morphometric AgNOR parameters (argyrophilic nucleolar organiser region-associated proteins) and MIB1 growth fraction, and (ii) their correlation with immunohistochemical p53, sex steroid receptor status and histopathological differentiation grade in serial paraffin sections from 39 breast carcinomas. Ten sections were double-stained for AgNOR/MIB1. AgNOR parameters correlated significantly with MIB1 growth fraction and p53 protein expression. Significant inverse correlation was found between proliferation markers and oestrogen/progesterone receptor status and histopathological grade. AgNOR expression was significantly higher in cycling (MIB1 positive) tumour cells, than in resting (MIB1 negative) ones, however with exceptions. We conclude, that standardised AgNOR parameters correlate with markers of increased malignant potential in breast carcinomas. However, AgNORs seem to reflect proliferation independent cellular and nucleolar activity of tumour cells, as well. We recommend the use of standardised AgNOR analysis for obtaining sound results in routine paraffin sections.
\end{abstract}

Keywords: Breast cancer, standardised AgNOR analysis, MIB1, p53, ER, PR

\section{Introduction}

Several recently published breast cancer studies involving many hundreds of cumulative patients data report a significant relationship between increased tumour proliferation indices and poor clinical outcome both in uni- and multivariate analysis [13,32,33,40,44]. One of the most commonly used method for proliferation assessment in oncology is the immunohistochemical estimation of the growth rate in histological material by using the anti-Ki-67 antibody [18] which reacts with a non-histone nuclear antigen present in all phases of the cell cycle except $G_{0}$ and early $G_{1}$ [17]. The need for fresh frozen material for such investigations has recently been overcome by the development of an anti-Ki-67 analogous monoclonal antibody (MIB1) which can be applied on routinely processed tissues after citrate-mediated high temperature antigen retrieval [3,8]. However, MIB1 staining and quantitation still requires standardisation.

\footnotetext{
${ }^{*}$ Correspondence to: Werner Böcker, M.D., Professor of Pathology, Department of Pathology, Domagkstrasse 17, D-48149 Münster, Germany. Tel.: +49 25183 55440/1; Fax: +49 2518355481.
} 
It should also be considered that labelling indices of any kind provide static, quantitative measures of the actual amount of cells in the cell cycle and does not reflect the real dynamism of proliferation. Other techniques, such as morphometric analysis of silver stained nucleolar organiser-associated proteins (AgNORs) have been shown to yield more relevant information concerning time-related dimensions of cell division $[10,11,28]$.

AgNOR proteins play a fundamental role in the control of ribosomal RNA (rRNA) transcription and processing and are defined as markers of "active" ribosomal genes. The close relationship between the rate of cell proliferation and ribosomal biogenesis is well established. Several studies revealed a linear correlation between AgNOR counts and the growth fraction (Ki-67 scores) in different malignancies including that of the breast $[12,19,20,22,36,43]$. Our recent studies showed, that AgNOR parameters represent highly significant and independent prognostic markers in several human malignancies [29, $30,34,35,42]$, including carcinoma of the breast [27], by using the recently standardised technique of AgNOR analysis [25,26]. Initial studies indicate its predictive value in response to anti-tumour therapy of colonic [31] and breast cancer, as well (data not published).

However, the main AgNOR proteins in nucleoli during interphase were found to be different from those associated with ribosomal genes during mitosis [38] and interphase AgNORs were found to be involved, besides proliferation, in other cellular activities, e.g., transformation, differentiation, as well [37].

The present study was designed to investigate (i) the relationship between dynamic and static markers of proliferation, namely standardised morphometric AgNOR parameters and the MIB1 growth fraction, and (ii) their association with established markers of differentiation (ER, PR-status, grade) and cell cycle regulation (p53) in breast cancer. Our aim was to extend previous prognostic studies of our group and investigate the potential biological background which underlies the highly significant and independent prognostic value of standardised AgNOR parameters in breast carcinoma.

\section{Materials and methods}

Thirty nine invasive breast carcinoma specimens [31 of ductal and 8 of lobular differentiation, ( 8 grade I, 19 grade II, 12 grade III)] and 5 normal breast tissues for control purposes were retrieved from the files of the Gerhard-Domagk Institute of Pathology, University of Münster, Germany. Tissue samples were routinely processed (fixed in buffered formalin and embedded in paraffin) and diagnosed on haematoxylin-eosin stained sections. Histopathological grading of the tumours were carried out by two pathologists (A.B., W.B.) according to the criteria described by Ellis and Elston [15]. The tissue samples constituted a part of a previous prognostic study of AgNORs in breast cancer [27]. Eight serial sections were prepared from each tissue block. An additional section was cut from 10 invasive carcinomas and from the normal controls for double AgNOR/MIB1 reaction.

\subsection{AgNOR staining and morphometric analysis}

Two $\mu \mathrm{m}$ thick paraffin sections were layed and dried on xylene coated glass slides, dewaxed, and rehydrated through a series of graded ethanols according to routine protocols. Subsequently, sections were immersed in citrate buffer ( $0.01 \mathrm{M}$ sodium-citrate monohydrate, $\mathrm{pH}$ 6.0) and incubated in a Gössner autoclave [GLA 40-2 (bench-type)] at $120^{\circ} \mathrm{C}$ for $20 \mathrm{~min}$ for protein retrieval. Silver-staining was performed in a freshly prepared solution containing one part by volume of $2 \%$ gelatine in $1 \%$ formic acid and two parts of aqueous silver nitrate solution for $25 \mathrm{~min}$ at room temperature as described by Öfner et al. [26]. 
After thorough rinsing in distilled water, sections were dehydrated, cleared in xylene and mounted with Vitroclud (all chemicals were purchased from Merck, Darmstadt, Germany).

The AgNOR content of at least 200 nuclei were evaluated in histologically identified areas at $400 \times$ magnification at one focal plan - by one of the authors (K.J.Sch.) using a semi-automated imageanalysing system (Zeiss Axioscop microscope, JVC TK 1070E colour video camera, with a 80486 based microcomputer equipped with a digitised board, and software application based on VIDAS release 2.5 from Kontron Elektronik GmbH, Germany). The area and number of AgNORs per nuclei were measured simultaneously and are given as the mean; the area of AgNORs were calibrated to $\mu \mathrm{m}^{2}$. The respective coefficients of variation (CV; defined as the standard deviation divided by the mean) were calculated for each measurement. In normal control sections only luminal epithelial cells were evaluated. The AgNOR analysis was in accordance with the recommendations of the 'Committee on AgNOR Quantification' within the European Pathological Society [2].

\subsection{MIB1 immunostaining and labelling index (LI)}

Section preparation, wet autoclave pre-treatment for antigen retrieval and immunostaining were performed as described elsewhere [3]. In short: $10 \mathrm{~min}$ autoclave pre-treatment followed by overnight incubation with the MIB1 antibody $(1: 500)$. The secondary immunoreactions were carried out by using the APAAP method with subsequent Fast Red development. The MIB1 LI (percentage of MIB1 positive stained cells of the total number of cells counted) was estimated by one of the authors (T.M.) by enumerating at least 500 tumour cell nuclei at the most immunreactive parts of the tumours (at the advancing tumour front). In control sections of normal breast tissues the MIB1 positive ratio was calculated in at least 100 cells counted in the luminal epithelial cell compartment.

\section{3. p53 immunostaining}

The following primary antibodies were used: CM1, PAb1801, DO7, PAb240 (all purchased from Medac, Hamburg, Germany). Optimal immunostaining conditions had been established for each antibody in preliminary experiments [3]. For secondary immunohistochemical reactions the alkaline phosphataseanti alkaline phosphatase (APAAP) method was used. Enzymatic development was carried out using a freshly prepared Fast Red solution. Omission of the primary antibodies served as negative controls. Sections from a colonic carcinoma (containing genetically proven p53 alteration with p53 gene product accumulation) were included as positive control. Immunoreactions were scored on the basis of integrating staining intensity and proportion of tumour cells stained on a 5 grade scale: negative, scattered, weak, moderate, strong (Table 1).

\subsection{Oestrogen and progesterone receptor immunostaining}

The oestrogen and progesterone receptor status of the tumours were determined as previously described by our group [5] by using the monoclonal antibodies 1D5.26 (Dianova, Hamburg, Germany) and 10A9 (Coulter/Immunothech, Hamburg, Germany), respectively, following wet autoclave antigen retrieval. Evaluation was carried out semiquantitatively similarly to p53 assessment. For statistical analysis negative and positive groups were created. 
Table 1

\begin{tabular}{ll}
\multicolumn{2}{c}{ Evaluation of p53, ER, PR immunoreactions } \\
\hline $\begin{array}{l}\text { Strong } \\
\text { Moderate }\end{array}$ & $\begin{array}{l}\text { Dark immunostaining in }>50 \% \text { of the tumour cells } \\
\text { Focal, dark immunostaining in 10-50\%, or moder- } \\
\text { ate immunostaining in }>50 \% \text { of the tumour cells }\end{array}$ \\
Weak & $\begin{array}{l}\text { Focal, moderate immunostaining in 10-50\%, or } \\
\text { weak immunostaining in any proportion of tumour } \\
\text { cells }\end{array}$ \\
Scattered & $\begin{array}{l}\text { Dark immunostaining of widely scattered tumour } \\
\text { cells }(<10 \%)\end{array}$ \\
Negative & Tumours completely lacking immunostaining \\
\hline
\end{tabular}

\subsection{Double staining for AgNORs and MIB1}

For sequential double staining, MIB1 immunreaction and enzyme development was carried out as a first step by using a high dilution $(1: 5000)$ of the MIB1 antibody for achieving better discrimination of AgNORs in MIB1 positive cells. Subsequent to thorough rinsing of MIB1 stained sections in distilled water, silver staining for AgNORs was carried out as described above.

\subsection{Comparison of AgNOR content and immunohistochemical reactions in serial sections}

AgNOR analysis was performed at histologically identical areas, namely at the advancing edge of invasive carcinomas and in luminal epithelial cells in normal breast control tissues. MIB1, p53, ER and PR assessment was also carried out at identical sites in serial sections.

\subsection{AgNOR content of MIB1-positive (cycling) and MIB1-negative (non-cycling) tumour cells}

The AgNOR content was measured separately both in MIB1-negative and MIB1-positive tumour cells in double-stained sections. The colour monitor made it possible to distinguish between cycling and noncycling cells.

\subsection{Statistical analysis}

Statistical analysis was carried out using the SPSS 6.1 for Windows software. Descriptive statistics for continuous measures are given as the mean with the respective coefficients of variation $(\mathrm{CV})$. The relation of AgNOR parameters between different groups were tested by the non-parametric Kruskal-Wallis test and the Mann-Whitney $U$ test (whenever appropriate). Correlation between AgNOR parameters and immunohistochemical reactions were analysed by using the Pearson correlation matrix.

\section{Results}

\subsection{AgNOR analysis}

In all specimens investigated, AgNORs were observed as well defined, clearly distinguishable black dots within nucleoli following wet autoclave pre-treatment. The distribution of standardised AgNOR parameters (mean AgNOR area and number per nucleus, respective CVs) is summarised in Table 2. 
Table 2

Standardised AgNOR parameters and MIB1 score in normal and carcinoma samples of the breast

\begin{tabular}{|c|c|c|c|c|c|c|}
\hline \multirow[t]{2}{*}{ Diagnosis } & \multirow[t]{2}{*}{$n$} & \multicolumn{4}{|c|}{ AgNOR parameters } & \multirow{2}{*}{$\begin{array}{c}\text { MIB1-score } \\
\text { Mean } \\
(\text { min-max }) \\
\text { median } \\
\end{array}$} \\
\hline & & $\begin{array}{c}\text { Mean of area } \\
(\min -\max ) \\
\text { median }\end{array}$ & $\begin{array}{c}\text { CV of area } \\
(\text { min-max }) \\
\text { median }\end{array}$ & $\begin{array}{c}\text { Mean of number } \\
(\min -\max ) \\
\text { median }\end{array}$ & $\begin{array}{c}\text { CV of number } \\
(\text { min-max }) \\
\text { median }\end{array}$ & \\
\hline Normal & & $\begin{array}{c}1.71 \\
(1.40-1.85)\end{array}$ & $\begin{array}{c}0.30 \\
(0.21-0.37)\end{array}$ & $\begin{array}{c}1.33 \\
(1.24-1.43)\end{array}$ & $\begin{array}{c}0.42 \\
(0.40-0.44)\end{array}$ & $\begin{array}{c}1.6 \\
(1-3)\end{array}$ \\
\hline & & 1.77 & 0.30 & 1.32 & 0.43 & 2 \\
\hline ID & 31 & $\begin{array}{c}2.52 \\
(0.43-5.59)\end{array}$ & $\begin{array}{c}0.38 \\
(0.29-0.59)\end{array}$ & $\begin{array}{c}2.04 \\
(1.33-4.31)\end{array}$ & $\begin{array}{c}0.45 \\
(0.36-0.54)\end{array}$ & $\begin{array}{c}45 \\
(1-78)\end{array}$ \\
\hline & & 2.35 & 0.37 & 1.94 & 0.45 & 45 \\
\hline IL & 8 & $\begin{array}{c}2.17 \\
(1.82-3.25)\end{array}$ & $\begin{array}{c}0.36 \\
(0.30-0.43)\end{array}$ & $\begin{array}{c}1.67 \\
(1.33-2.01)\end{array}$ & $\begin{array}{c}0.44 \\
(0.37-0.49)\end{array}$ & $\begin{array}{c}12.4 \\
(1-39)\end{array}$ \\
\hline & & 1.95 & 0.36 & 1.75 & 0.42 & 12 \\
\hline All carcinomas & 39 & $\begin{array}{c}2.45 \\
(0.43-5.58) \\
2.30\end{array}$ & $\begin{array}{c}0.37 \\
(0.29-0.59) \\
0.37\end{array}$ & $\begin{array}{c}1.96 \\
(1.33-4.31) \\
1.83\end{array}$ & $\begin{array}{c}0.45 \\
(0.36-0.54) \\
0.45\end{array}$ & $\begin{array}{c}39 \\
(1-78) \\
39\end{array}$ \\
\hline
\end{tabular}

Abbreviations: $n=$ number of cases, ID = invasive ductal carcinoma, $\mathrm{IL}=$ invasive lobular carcinoma, $\mathrm{CV}=$ coefficient of variation, $\min =$ minimal value, $\max =$ maximal value.

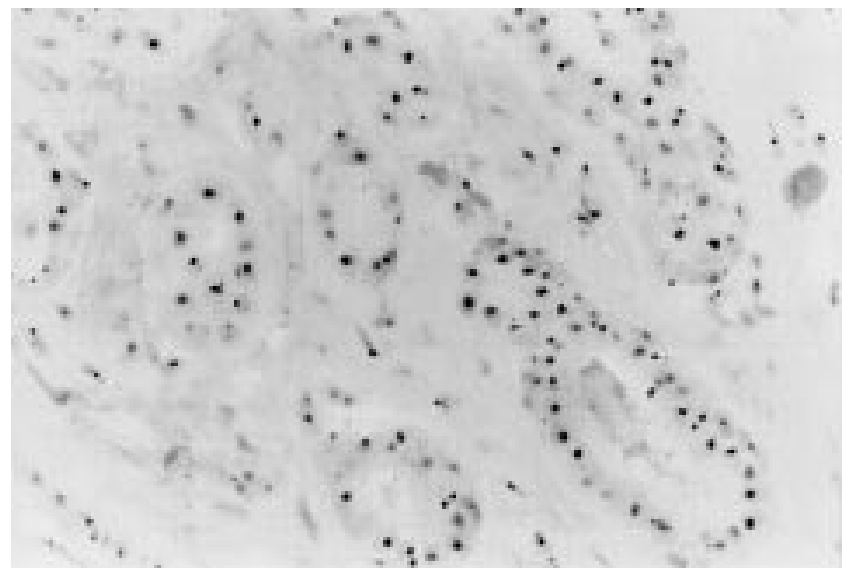

Fig. 1. Appearance of AgNORs in normal breast epithelial cells following standardised AgNOR-staining $(\times 400)$.

All 4 AgNOR parameters were statistically significantly related in the 39 invasive carcinomas measured. Statistically high significant correlation was found between mean values of AgNOR area and number ( $R=0.773$ ), as well as between the CVs of area and number of AgNORs ( $R=0.747)$. Mean AgNOR values with their respective CVs were less significantly related or not at all (CV of area versus mean of area: $R=0.483$; CV of number versus mean of number: $R=0.211$, respectively) (Table 3 ).

\subsubsection{Normal breast tissue}

Resting luminal epithelial cells contained 1-2 min AgNOR dots (Fig. 1). Mean values of AgNOR parameters were as follows: area: $1.713 \mu \mathrm{m}^{2}$; number: 1.326 ; $\mathrm{CV}$ of area: 0.297 ; CV of number: 0.423 . 


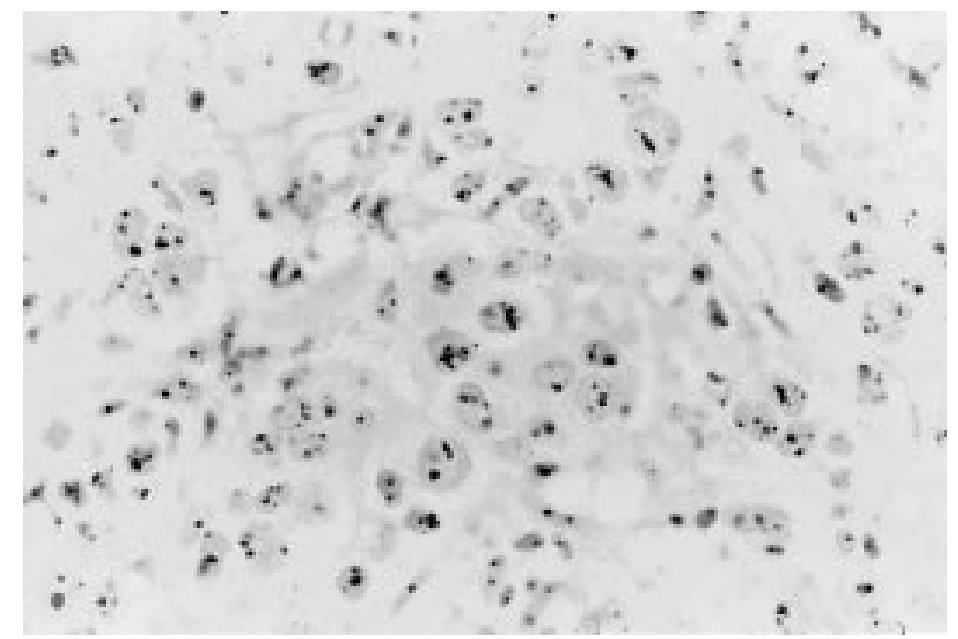

Fig. 2. High amount of AgNORs in an invasive ductal breast carcinoma of histopathological differentiation grade $3(\times 400)$.

\subsubsection{Invasive ductal carcinomas (ID)}

Invasive ductal carcinomas were characterised by a statistically highly significant increase in the amount of AgNORs compared to control normal samples $(P<0.001)$ reflected by all AgNOR parameters (Fig. 2).

\subsubsection{Invasive lobular carcinomas (IL)}

The statistically highly significantly increased AgNOR content of tumours compared to normal control was reflected by both the mean and the CV of AgNOR number $(P<0.001$ for both). A significant increase of the mean AgNOR area has also been detected $(P=0.018)$.

\subsection{MIB1 scores}

Positive staining for MIB1 was evident in each section as a diffuse nuclear staining with accentuation of the nucleoli and the condensed chromosomes in mitotic cells. Distribution of MIB1 scores in different diagnostic groups is presented in Table 2 .

\subsubsection{Normal breast tissue}

MIB-1 positivity could be detected only in very few luminal and basal/parabasal epithelial cells (mean: $1.6 \%$; range: 1-3), myoepithelial cells remained consistently negative (Fig. 3).

\subsubsection{Invasive breast carcinomas}

Of particular note was the heterogeneous distribution of MIB1 positive tumour cells in a given tumour showing accumulation at the most invasive peripheral parts of the carcinomas and diminished proliferative activity in the tumour core. The mean growth fraction of invasive carcinomas was $35.7 \%$ (range 1-78\%). Generally, invasive ductal carcinomas revealed higher MIB1 scores than lobular ones. The difference between proliferation indices of normal breast epithelium and invasive carcinomas was highly significant $(P<0.001)$.

\subsubsection{Correlation between MIB1 labelling indices (LI) and AgNOR parameters}

There was slightly and moderately significant correlation between MIB1 scores and the respective mean AgNOR number and CV of AgNOR number parameters $(R=0.364$ and 0.479 , respectively) (Table 3). 


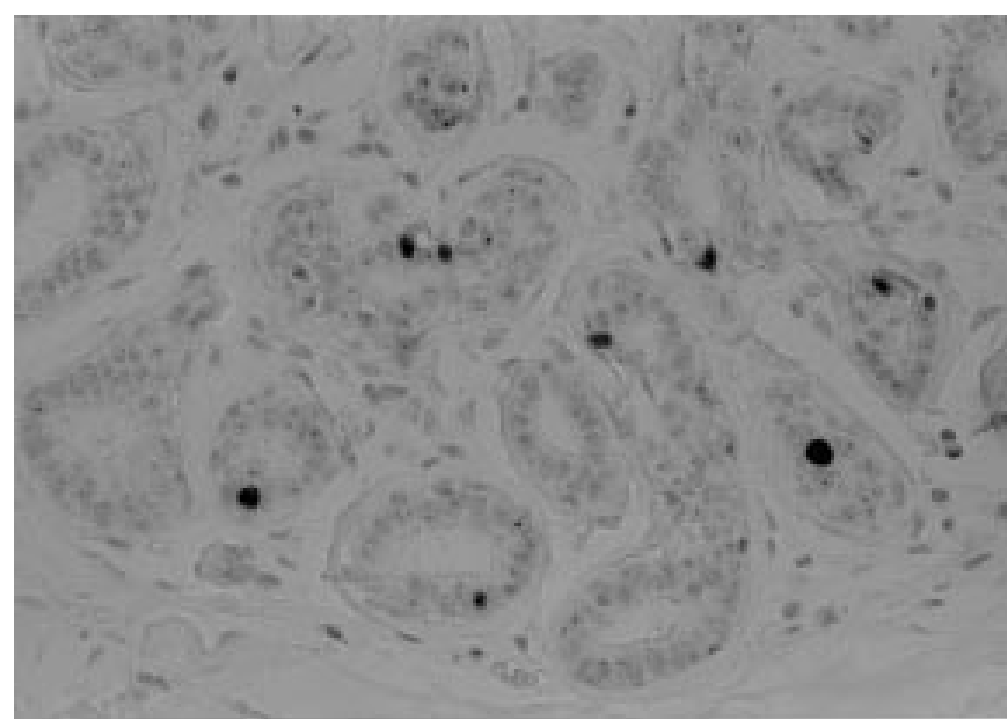

Fig. 3. MIB1 immunoreactivity in normal breast epithelium $(\times 250)$.

Table 3

Correlation between MIB1 scores, AgNOR parameters, ER-, PR-, p53 immunostatus and histopathological grade (Pearson's pairwise correlation)

\begin{tabular}{|c|c|c|c|c|c|c|c|c|}
\hline Parameters & $\begin{array}{c}\text { Mean AgNOR } \\
\text { area }\end{array}$ & $\begin{array}{c}\mathrm{CV} \text { of AgNOR } \\
\text { area }\end{array}$ & $\begin{array}{c}\text { Mean AgNOR } \\
\text { number }\end{array}$ & $\begin{array}{c}\mathrm{CV} \text { of AgNOR } \\
\text { number }\end{array}$ & MIB1-LI & $\overline{E R}$ & $\overline{P R}$ & p53 \\
\hline $\begin{array}{l}\text { Mean AgNOR } \\
\text { area }\end{array}$ & 1 & & & & & & & \\
\hline $\begin{array}{l}\mathrm{CV} \text { of } \mathrm{AgNOR} \\
\quad \text { area }\end{array}$ & $\begin{array}{c}0.483 \\
P=0.00\end{array}$ & & & & & & & \\
\hline $\begin{array}{l}\text { Mean AgNOR } \\
\text { number }\end{array}$ & $\begin{array}{c}0.773 \\
P=0.00\end{array}$ & $\begin{array}{c}0.747 \\
P=0.00\end{array}$ & & & & & & \\
\hline $\begin{array}{l}\mathrm{CV} \text { of AgNOR } \\
\text { number }\end{array}$ & $\begin{array}{c}0.012 \\
\text { n.s }\end{array}$ & $\begin{array}{c}0.392 \\
P=0.01\end{array}$ & $\begin{array}{c}0.211 \\
\text { n.s }\end{array}$ & & & & & \\
\hline MIB1-LI & $\begin{array}{c}0.281 \\
\text { n.s }\end{array}$ & $\begin{array}{c}0.309 \\
P=0.05\end{array}$ & $\begin{array}{c}0.364 \\
P=0.02\end{array}$ & $\begin{array}{c}0.479 \\
P=0.00\end{array}$ & & & & \\
\hline ER & $\begin{array}{l}-0.4728 \\
P=0.02\end{array}$ & $\begin{array}{c}-0.378 \\
\text { n.s }\end{array}$ & $\begin{array}{l}-0.5966 \\
P=0.00\end{array}$ & $\begin{array}{c}0.015 \\
\text { n.s }\end{array}$ & $\begin{array}{c}-0.5538 \\
P=0.00\end{array}$ & & & \\
\hline PR & $\begin{array}{c}-0.315 \\
\text { n.s }\end{array}$ & $\begin{array}{c}-0.246 \\
\text { n.s }\end{array}$ & $\begin{array}{c}-0.419 \\
P=0.05\end{array}$ & $\begin{array}{c}-0.2241 \\
\text { n.s }\end{array}$ & $\begin{array}{c}-0.789 \\
P=0.00\end{array}$ & $\begin{array}{c}0.717 \\
P=0.00\end{array}$ & & \\
\hline p53 & $\begin{array}{c}0.2527 \\
\text { n.s }\end{array}$ & $\begin{array}{c}0.4393 \\
P=0.01\end{array}$ & $\begin{array}{c}0.394 \\
P=0.03\end{array}$ & $\begin{array}{c}0.1861 \\
\text { n.s }\end{array}$ & $\begin{array}{c}0.3987 \\
P=0.03\end{array}$ & $\begin{array}{c}-0.411 \\
P=0.06\end{array}$ & $\begin{array}{c}-0.289 \\
\text { n.s }\end{array}$ & \\
\hline Grade & $\begin{array}{c}0.183 \\
\text { n.s }\end{array}$ & $\begin{array}{c}0.2794 \\
\text { n.s }\end{array}$ & $\begin{array}{c}0.3955 \\
P=0.01\end{array}$ & $\begin{array}{c}0.4425 \\
P=0.00\end{array}$ & $\begin{array}{c}0.616 \\
P=0.00\end{array}$ & $\begin{array}{c}-0.592 \\
P=0.00\end{array}$ & $\begin{array}{c}-0.711 \\
P=0.00\end{array}$ & $\begin{array}{c}0.408 \\
P=0.03\end{array}$ \\
\hline
\end{tabular}

Abbreviations: $n=$ number of cases, ID $=$ invasive ductal carcinoma, MIB1-LI $=$ MIB1 labelling index, $\mathrm{IL}=$ invasive lobular carcinoma, $\mathrm{ER}=$ oestrogen receptor, $\mathrm{PR}=$ progesterone receptor, $\mathrm{CV}=$ coefficient of variation. 


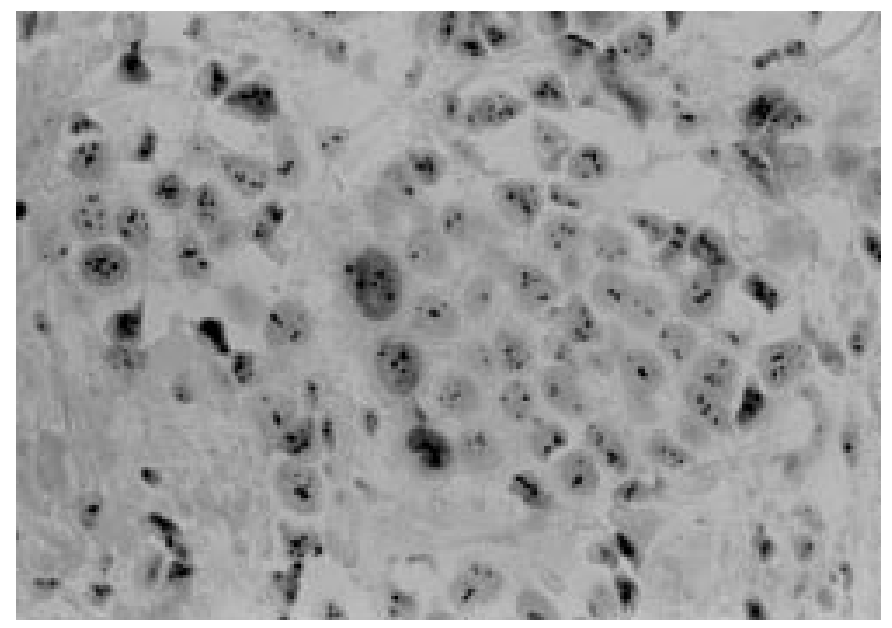

Fig. 4. Double staining for AgNORs and MIB1 in an invasive ductal carcinoma $(\times 400)$.

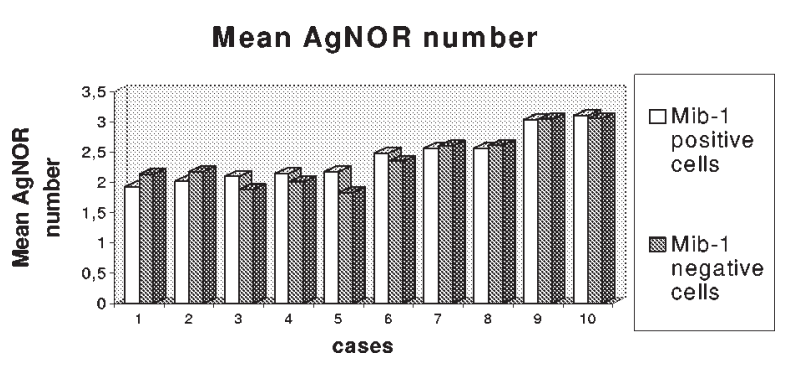

Mean AgNOR area

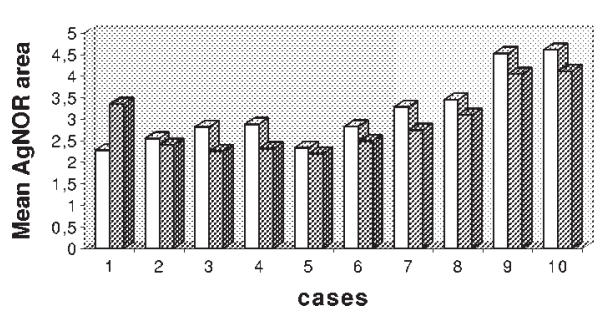

CV AgNOR number

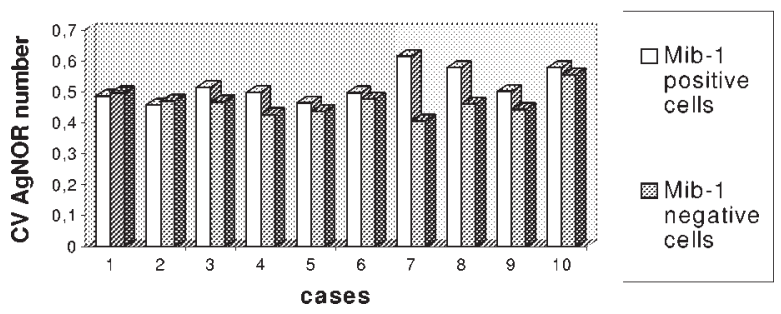

CV AgNOR area

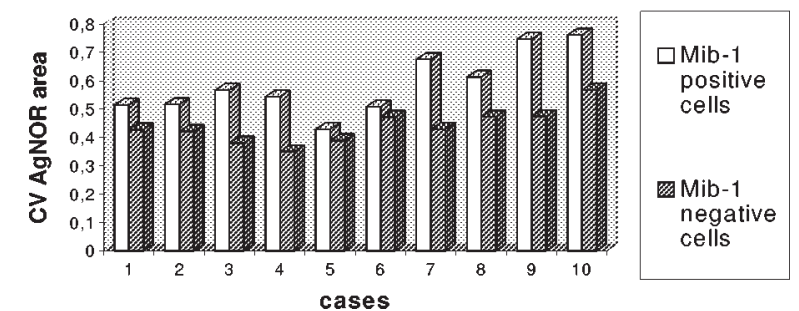

Fig. 5. Statistical distribution of standardised AgNOR parameters in MIB1 positive and MIB1 negative tumour cells in 10 invasive ductal carcinomas investigated by double staining.

\subsubsection{Correlation between AgNOR content of cycling (MIB1 positive) and non-cycling (MIB1 negative) invasive ductal carcinoma (ID) cells}

MIB1 positive cells contained generally more AgNORs than MIB1 negative cells in a given tumour in the group of 10 carcinomas investigated by double staining (Figs 4 and 5). There was a statistically highly significant difference between AgNOR patterns of MIB1 positive and negative tumour cells reflected by both the $\mathrm{CV}$ of area $(Z=-3.326$; 2-tailed $P=0.005)$ and the $\mathrm{CV}$ of number $(Z=-2.495$; 2-tailed $P=0.013$ ) (Mann-Whitney $U$ test), whereas the mean values of AgNOR number and area did not differ significantly between cycling and non-cycling tumour cells $(Z=-0.1891$, and $Z=-1.589$, respectively). 


\section{3. p53, oestrogen $(E R)$ and progesterone receptor $(P R)$ immunohistochemistry}

The immunoreactivity of p53 was considered to express p53 overexpression, if distinct nuclear staining was present showing a reaction pattern of weak, moderate or strong with at least one anti-p53 antibody used. Cases with 'scattered' p53 positivity were assessed together with the group of 'p53-negative' carcinomas. This corresponds to the classification used by several other workers taking $10 \%$ as a cut off value for p53 overexpression. In control normal breast tissues no p53 immunoreactivity was found. In invasive carcinomas, the reaction pattern of the 4 anti-p53 antibodies was almost identical with statistically highly significant correlation (Pearson's $R$ : 0.61-0.93). Therefore, in the following we report on the reactivity of the PAb1801 antibody. Invasive carcinomas revealed p53 overexpression in the present cohort of tumours studied 5/39 (13\%). p53 overexpression correlated significantly with increased mean AgNOR number $(P=0.03), \mathrm{CV}$ of AgNOR area $(P=0.01)$, high MIB1 LIs $(P=0.03)$, poor differentiation grade $(P=0.03)$ and there was a trend to association with negative ER status (Table 3$)$.

Similarly to p53 assessment, ER and PR immunoreactivity was considered positive, if distinct nuclear staining was present showing a reaction pattern of weak, moderate or strong. Cases with 'scattered' positivity were assessed together with the group of receptor negative carcinomas. ER expression was significantly correlated with lower mean values of AgNOR area $(P=0.02)$ and number $(P=0.003)$, smaller MIB1 LIs $(P=0.008)$, PR positivity $(P=0.000)$ and well-differentiated histopathological grade $(P=0.005)$. PR expression was significantly correlated with lower mean value of AgNOR number $(P=0.05)$, low MIB1 LI $(P=0.000)$, ER positivity $(P=0.000)$ and well-differentiated histopathological grade $(P=0.000)$ (Table 3$)$.

\section{Discussion}

Several recent studies have assessed 'proliferative activity' in breast cancer by analysing different parameters of tumour growth. Linear correlation was reported between the Ki-67 determined growth fraction and the mitotic index [4], thymidine labelling index [23], S-phase fraction [16] and DNA ploidy [7]. Furthermore, significant relationship was found between the expression of interphase AgNORs and other cell kinetic parameters, such as tumour doubling time, S-phase fraction and Ki-67/MIB1 immunoreactivity $[12,28,39]$, as well. Significant correlation has been reported between proliferation markers and steroid receptor expression as well as histopathological tumour grade by many investigators $[1,14,27,32$, 39]. The results of the present study are in line with most of these findings and indicate that proliferationassociated parameters (AgNORs, MIB1 growth fraction, p53 status) are inversely correlated with differentiation markers (ER, PR, histopathological grade) in breast cancer. This supports the well established view, that proliferating cells, or those with deranged proliferation regulation, usually do not differentiate and, conversely, cells when differentiating, usually cease dividing.

An increased proliferation rate has also been directly related to poor clinical outcome in breast carcinomas [16,21]. In a recent study, in partial accordance with other researchers [1], we have shown the independent prognostic value of standardised AgNOR parameters in this type of cancer [27]. However, the underlying biological mechanisms are poorly understood as yet. It has repeatedly been experimentally shown, that the amount of interphase AgNORs is linearly correlated to the cell doubling time in vitro [10, $11,28]$ and it is the only parameter so far, that allows estimation of the rapidity of the cell cycle in routinely processed histological sections.

To the best of our knowledge, the present study is the first approach to simultaneous assessment of standardised AgNOR parameters and MIB1 growth fraction in serial and double-stained archival breast 
carcinoma sections. We found slight to moderately significant correlation between the MIB1 growth fraction and standardised AgNOR parameters in partial accordance with other workers, who reported on highly significant correlation [12,14,24]. It has to be repeatedly stressed, that previous AgNOR studies varied very much concerning technical aspects of tissue fixation, processing, silver staining and quantitation. Therefore the inter-laboratory agreement between results is poor.

We found by using standardised AgNOR analysis a significantly higher AgNOR expression pattern (reflected by the CVs of AgNOR number and area) in the population of cycling tumour cells than in resting ones, indicating an increased activity of protein synthesis in dividing tumour cells. Conversely, the actual amount of AgNOR proteins (revealed by the AgNOR mean area and number) was not different. This finding highlights the significance of the use of CV values in AgNOR analysis in keeping with recommendations of other researchers [9]. The occasionally higher AgNOR amount in MIB1 negative cells compared to MIB1 positive ones may reflect transcriptional activity in mitotically quiescent cells $\left(\mathrm{G}_{0}\right)$ or in cells at the beginning of the cell cycle (early $\mathrm{G}_{1}$ ). This may underlie the diminished correlation we found between AgNORs and MIB1 growth fraction. Although we could clearly observe an enhanced MIB-1 staining of nucleoli within MIB-1 positive nuclei, reflecting the specific reactivity of MIB1 with a non-histone nuclear protein, it did not hinder morphometric AgNOR-analysis.

Intriguingly, a recent study on non-small cell lung cancer reports on the significant prognostic value of AgNORs in Ki67 positive cycling tumour cells in contrast to the actual growth rate [6]. Our present study on a small cohort of breast carcinomas allows no prognostic analysis but provides a sound methodical basis for future investigations of this kind. However, AgNORs as pure proliferation markers should be critically interpreted, since interphase AgNOR expression is likely to be influenced by other transcriptional activities of a cell independent of proliferation as well, e.g., there is evidence that AgNOR quantity can reflect the state of cellular differentiation [37] or it can be 'inherited' from the previous cell cycle [41].

We conclude that breast carcinomas are heterogeneous with respect to their growth potential (MIB1 labelling indices) and growth speed (AgNOR expression), and proliferation-associated parameters are inversely correlated with differentiation markers in this type of cancer. It remains to be elucidated how the different growth-kinetic-phenotypes may predict therapy response of a given tumour and survival of an individual patient. For such investigations standardised and objective methods in staining and evaluation of proliferation markers are inevitable.

\section{References}

[1] M. Aubele, G. Auer, P. Gais, U. Jütting, K. Radenacker and A. Voss, Nucleolus organiser regions (AgNORs) in ductal mammary carcinoma. Comparison with classification and prognosis, Pathol. Res. Pract. 190 (1994), 129-137.

[2] M. Aubele, S. Biesterfeld, M. Derenzini, P. Hufnagl, H. Martin, D. Öfner, D. Ploton and J. Rüschoff, Guidelines of AgNOR quantitation, Zentralbl. Pathol. 140 (1994), 107-108.

[3] À. Bànkfalvi, H. Navabi, B. Bier, W. Böcker, B. Jasani and K.W. Schmid, Wet autoclave pretreatment for antigen retrieval in diagnostic immunohistochemistry, J. Pathol. 174 (1994), 223-228.

[4] N.J. Barnard, P.A. Hall, N.R. Lemoine and N. Kadar, Proliferative index in breast carcinoma determined in situ by Ki-67 immunostaining and its relationship to clinical and pathological variables, J. Pathol. 152 (1987), 287-295.

[5] B. Bier, À. Bànkfalvi, L. Grote, S. Blasius, D. Öfner, W. Böcker, B. Jasani and K.W. Schmid, Wet autoclave pretreatment for immunohistochemical demonstration of oestrogen receptors in routinely processed breast carcinoma tissue, Histochem. J. 27 (1995), 148-154.

[6] G. Bigras, R. Marcelpoil, E. Brambilla and G. Brugal, Interest of targeting AgNORs measurement in cycling cells: in vivo cell kinetic evaluation of non-small cell lung cancer, Anal. Cell. Pathol. 11 (1996), 183-198. 
[7] S.T. Brower, S. Ahmed, P.I. Tartter, I. Bleiweiss and J.B. Amberson, Prognostic variables in invasive breast cancer: contribution of comedo versus noncomedo in situ component, Ann. Surg. Oncol. 2 (1995), 440-444.

[8] G. Cattoretti, M.H. Becker, G. Key, M. Duchrow, C. Schulter, J. Galle and J. Gerdes, Monoclonal antibodies against recombinant parts of the Ki-67 antigen (MIB 1) and MIB 3) detect proliferating cells in microwave-processed formalinfixed paraffin sections, J. Pathol. 168 (1992), 357-363.

[9] M. Derenzini and D. Trerè, The coefficient of variation of AgNOR protein values: a standardised parameter for cell kinetics evaluation, Proc. Histochem. Soc. 40 (1992), 600.

[10] M. Derenzini and D. Trerè, AgNOR proteins as a parameter of the rapidity of cell proliferation, Zentralbl. Pathol. 140 (1994), 7-10.

[11] M. Derenzini, A. Pession and D. Trerè, The quantity of nucleolar silver stained proteins is related to proliferating activity in cancer cells, Lab. Invest. 63 (1990), 137-140.

[12] P.A. Dervan, L.G. Gilmartin, B. Loftus and D.N. Carney, Argyrophilic nucleolar organiser region counts correlate with Ki67 scores, Am. J. Clin. Pathol. 92 (1989), 401-407.

[13] P. Dettmar, N. Harbeck and C. Thomssen, Prognostic impact of proliferation associated factors MIB1 (Ki67) and S phase in node-negative breast cancer, Br. J. Cancer 75 (1997), 1525-1533.

[14] D. Di Stefano, P.L. Mingazzini, L. Scucchi, M. Doetti and V. Marinozzi, A comparative study on histopathology, hormone receptors, peanut lectin binding, Ki67 immunostaining and nucleolar organizer region-associated proteins in human breast cancer, Cancer 67 (1991), 463-471.

[15] I.O. Ellis and C.W. Elston, Pathological prognostic factors in breast cancer. I. The value of histological grade in breast cancer: experience from a large study with long term follow up, Histopathology 19 (1991), 403-410.

[16] G. Gasparini, P. Boracchi, P. Verderio and P. Bevilacqua, Cell kinetics in human breast cancer: comparison between the prognostic value of the cytofluorimetric S-phase fraction and that of the antibodies to Ki-67 and PCNA antigens detected by immunocytochemistry, Int. J. Cancer 57 (1994), 822-829.

[17] J. Gerdes, H. Lemke, H. Baisch, H.H. Wacker, U. Schwab and H. Stein, Cell cycle analysis of a cell proliferationassociated human nuclear antigen defined by the monoclonal antibody Ki-67, J. Immunol. 133 (1984), 1710-1715.

[18] J. Gerdes, U. Schwab, H. Lemke and H. Stein, Production of a mouse monoclonal antibody reactive with a human nuclear antigen associated with cell proliferation, Int. J. Cancer 31 (1983), 13-20.

[19] P.A. Hall, J. Crocker, A. Watts and A.G. Stansfeld, A comparison of nucleolar organiser region staining and Ki-67 immunostaining in non-Hodgkin's lymphoma, Histopathology 12 (1988), 373-381.

[20] A. Hara, H. Hirayama and N. Sakai, Correlation between nucleolar organiser region staining and Ki67 immunostaining in human gliomas, Surg. Neurol. 33 (1990), 320-324.

[21] V. Jensen, M. Ladekarl, P. Holm Nielsen, F. Melsen and F.B. Soerensen, The prognostic value of oncogenic antigen 519 (OA-519) expression and proliferative activity detected by antibody MIB-1 in node-negative breast cancer, J. Pathol. 176 (1995), 343-352.

[22] Y. Kakeji, D. Korenaga and S. Tsujitani, Predictive value of Ki67 and argyrophilic nucleolar organiser region staining for lymph node metastasis in gastric cancer, Cancer Res. 51 (1991), 3503-3506.

[23] O.W. Kamel, W.A. Franklin, J.C. Ringus and J.S. Meyer, Thymidine labeling index and Ki-67 growth fraction in lesions of the breast, Am. J. Pathol. 134 (1989), 107-113.

[24] W.A. Mourad, N. Sneige, R.L. Katz and N.G. Ordonez, Correlation of two AgNOR counts with Ki-67 labeling index: a study in fine-needle aspirates of lymphoproliferative disorders and breast carcinoma, Diagn. Cytopathol. 10 (1994), $113-119$.

[25] D. Öfner, M. Aubele, S. Biesterfeld, M. Derenzini, J.A. Giminez-Mas and P. Hufnagl, Guidelines of AgNOR quantification - first update, Virchows Arch. 427 (1995), 341-342.

[26] D. Öfner, À. Bànkfalvi, K. Riehemann, B. Bier, W. Böcker and K.W. Schmid, Wet autoclave pretreatment improves the visualisation of silver stained nucleolar organiser region associated proteins (AgNORs) in routinely formalin fixed and paraffin-embedded tissues, Mod. Pathol. 7 (1994), 946-450.

[27] D. Öfner, B. Bier, S. Heinrichs, M. Berghorn, M. Dünser and H.E. Hagemann, Demonstration of silver-stained nucleolar organiser regions associated proteins (AgNORs) after wet autoclave pretreatment in breast carcinoma, Breast Cancer Res. Treat. 39 (1996), 165-167.

[28] D. Öfner, A. Hittmair, C. Marth, C. Öfner, M. Tötsch and G. Daxenbichler, Relationship between quantity of silver stained nucleolar organizer regions associated proteins (AgNORs) and population doubling time in ten breast cancer cell lines, Path. Res. Pract. 188 (1989), 742-746.

[29] D. Öfner, B. Riedmann, H. Maier, A. Hittmair, A. Rumer and M. Tötsch, Standardised staining and analysis of argyrophilic nucleolar organiser region associated proteins (AgNORs) in radically resected colorectal adenocarcinoma - correlation with tumour stage and long-term survival, J. Pathol. 175 (1995), 441-448.

[30] D. Öfner, B. Riedmann, H. Maier, H. Weiss, G. Schwab and K.W. Schmid, Proliferative activity assessed by standardised AgNOR analysis: a major prognostic factor in radically resected gastric carcinoma, GCC Proc. 1 (1997), 555-558. 
[31] D. Öfner, H. Weiss, P. Sandblicher and H. Maier, Standardised AgNOR analysis in colorectal adenocarcinoma: correlation with chemotherapy efficacy, Cancer Detect. Prev. 20 (1996), 473-477.

[32] J.Y. Pierga, A. Leroyer, P. Viehl, V. Mosseri, S. Chevillard and H. Magdelenat, Long term prognostic value of growth fraction determination by Ki-67 immunostaining in primary operable breast cancer, Breast Cancer Res. Treat. 37 (1996), 57-64.

[33] T. Pietilainen, P. Lipponen, S. Aaltomaa, M. Eskelinen, V.M. Kosma and K. Syrjanen, The important prognostic value of Ki 67 expression as determined by image analysis in breast cancer, J. Cancer Res. Clin. Oncol. 122 (1996), 687-692.

[34] J. Piffkò, À. Bànkfalvi, D. Öfner, M. Bryne, D. Rasch and U. Joos, Prognostic value of histobiological factors (malignancy grading and AgNOR content) assessed at the invasive tumour front of oral squamous cell carcinomas, Br. J. Cancer 75 (1997), 1543-1546.

[35] J. Piffkò, À. Bànkfalvi, D. Öfner, D. Rasch, U. Joos and K.W. Schmid, Standardised AgNOR analysis of the invasive tumour front in oral squamous cell carcinomas, J. Pathol. 182 (1997), 450-456.

[36] W.A. Raymond and A.S. Leong, Nucleolar organiser regions related to growth fraction in human breast carcinoma, Human Pathol. 20 (1989), 741-746.

[37] B.R. Reeve, G. Casey, J.R. Honeycombe and A. Smith, Correlation of differentiation state and silver staining of nucleolar organizers in promyelocytic leukaemia cell line HL-640, Cancer Genet. Cytogenet. 13 (1984), 159-165.

[38] P. Roussel and D. Hernandez-Verdun, Identification of AgNOR proteins, markers of proliferation related to ribosomal gene activity, Exp. Cancer Res. 214 (1994), 465-472.

[39] M. Rudas, M.F. Gnant and M. Mittlbock, Thymidine labelling index and Ki-67 growth fraction in breast cancer: comparison and correlation with prognosis, Breast Cancer Res. Treat. 32 (1994), 165-175.

[40] R. Schwarting, Little missed markers and Ki 67, Lab. Invest. 68 (1993), 597-599.

[41] V. Sirri, A. Pession, D. Trerè, L. Montanaro and M. Derenzini, Proportionally constant quantitative transmission of nucleolin and protein B23 in cycling cancer cells, J. Clin. Pathol.: Mol. Pathol. 48 (1995), M264-M268.

[42] M. Tötsch, D. Öfner, H. Maier, S.B.C. Watzka, M. Salzer and K.W. Schmid, Argyrophilic nucleolar organiser regions associated proteins (AgNORs) in adenocarcinoma and squamous cell carcinoma of the lung - correlation with tumour stage and long-term survival, Pathol. Res. Pract. 191 (1995), 800-801.

[43] D. Trerè, F. Farabegoli and A. Cancellieri, AgNOR protein quantity in human tumours correlates with the proliferative activity evaluated by bromodeoxyuridine labelling and Ki67 immunostaining, J. Pathol. 164 (1991), 53-59.

[44] S.M. Veronese, C. Maisano and J. Scibilia, Comparative prognostic value of Ki-67 and MIB-1 proliferation indices in breast cancer, Anticancer Res. 15 (1995), 2717-2722. 


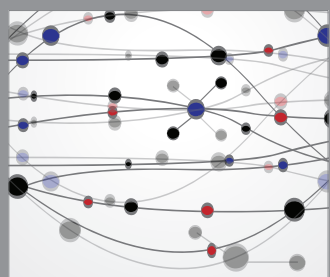

The Scientific World Journal
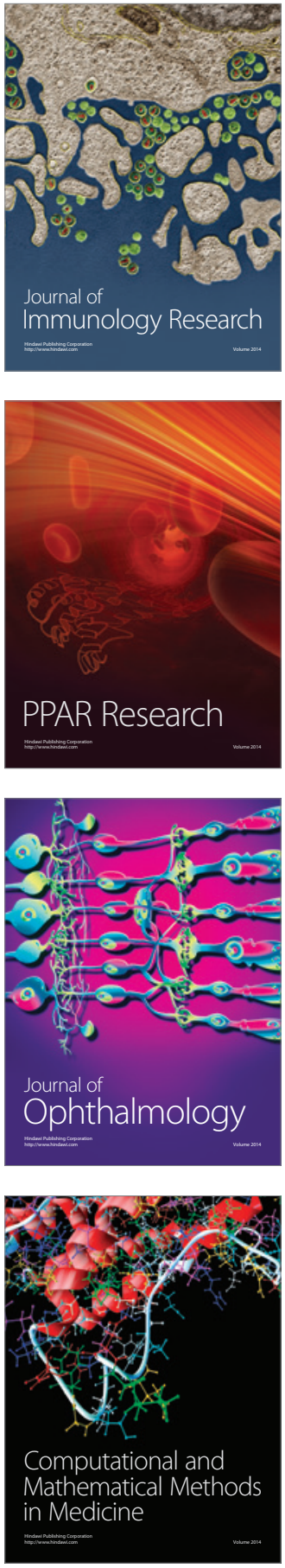

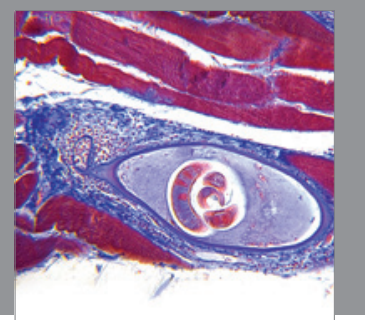

Gastroenterology

Research and Practice
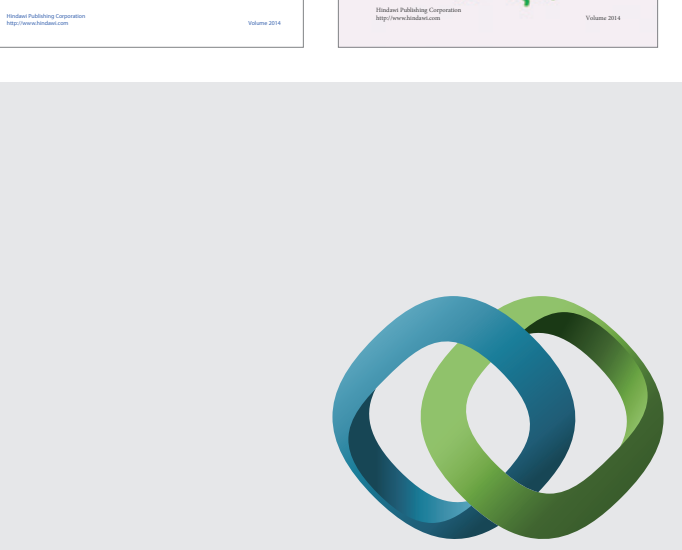

\section{Hindawi}

Submit your manuscripts at

http://www.hindawi.com
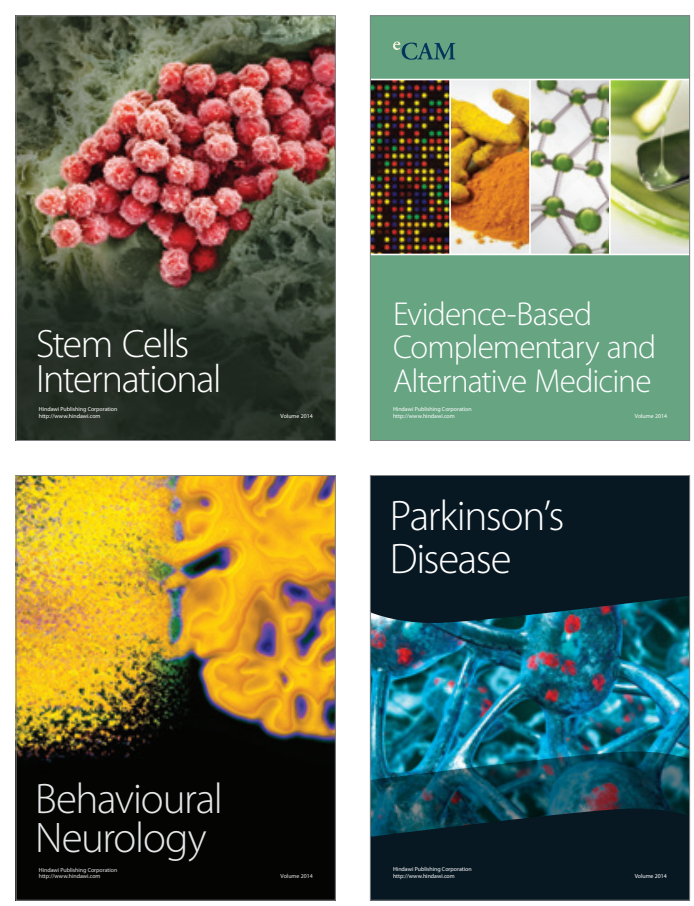

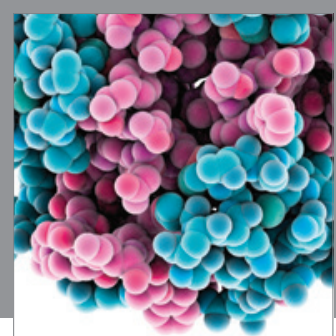

Journal of
Diabetes Research

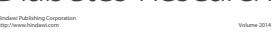

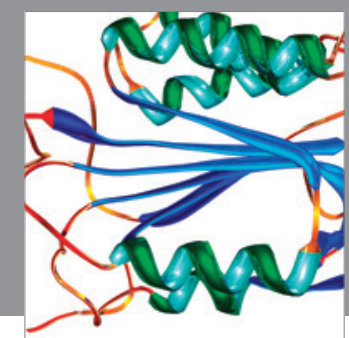

Disease Markers
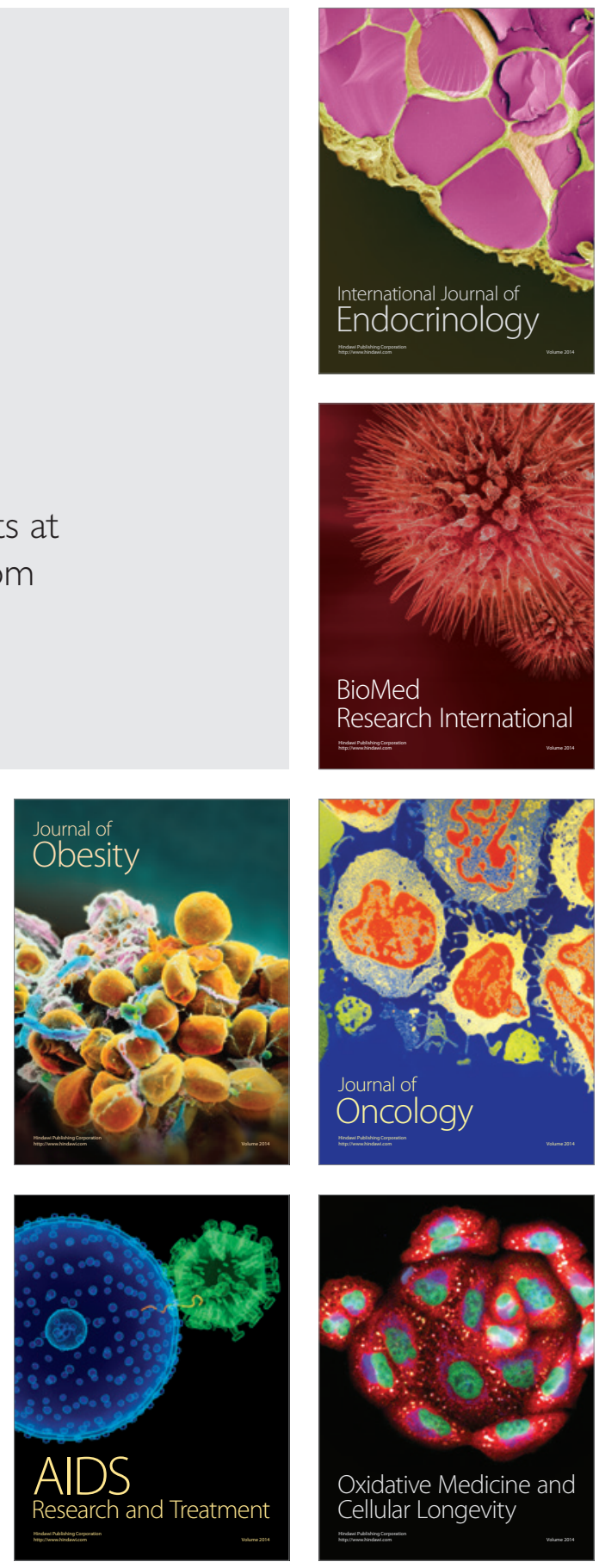